\title{
Deoxyribonucleic Acid Base Sequence Studies on Glucan- Producing and Glucan-Negative Strains of Streptococcus mitior
}

\author{
ALAN L. COYKENDALL AND ALLAN J. MUNZENMAIER \\ School of Dental Medicine, University of Connecticut, Farmington, Connecticut 06032
}

\begin{abstract}
The deoxyribonucleic acid base sequence similarities among 14 strains of Streptococcus mitior were assessed by hybridization. Some strains produce glucan. Deoxyribonucleic acid was purified by both a conventional method and by centrifugation in $\mathrm{CsCl}$. Hybridizations were done in solution with $\mathrm{S} 1$ nuclease and on membrane filters. The results showed two groups of moderately homologous strains. The glucan-producing strains represented a group which included some glucan-negative strains. Hybridization by the S1 method was less than with the filter method, indicating some sequence divergence within the two groups. There was a slight difference in guanine-plus-cytosine contents of the two groups.
\end{abstract}

Schottmüller used the name Streptococcus mitior seu viridans in 1903 for streptococci that were weakly hemolytic and produced small grey to greenish-black colonies (16). This name has priority over the binomial $S$. mitis, which was used in 1906 by Andrewes and Horder to designate streptococci which were rarely pathogenic, grew in short chains, and usually failed to ferment inulin and raffinose (1). Index Bergeyana (3) recognizes the binomial $S$. mitior (Schottmüller) as validly published and legitimate but regards $S$. mitis (Andrewes and Horder) illegitimate. It is difficult to know which of these early investigators' descriptions is better for these organisms, and it is likely that both Schottmüler and Andrewes and Horder studied streptococci of more than one species, if one applied current taxonomy. Andrewes and Horder suggested the name $S$. mitis as a "non-committal term fairly expressing its habitually non-virulent character" (1). Sherman et al. (17) discussed the heterogeneity of "S. mitis," and this species is still described as a "heterogeneous group" in Bergey's Manual of Determinative Bacteriology (8th ed.) (9). Lack of a clear definition of these cocci has limited the usefulness of the term $S$. mitis. The species has often been a receptacle for oral viridans streptococci which were not $S$. sanguis, $S$. salivarius, or $S$. mutans. Colman and Williams gave these organisms a clearer definition and recommended use of the earlier name $S$. mitior (5). Many microbiologists, especially oral microbiologists, now use this name for alpha-hemolytic streptococci that do not split esculin or arginine and do not ferment inulin.

Some "S. mitior-like" strains produce a polymer from sucrose which is regarded as a dextran or glucan (5). This property is shared by $S$. sanguis, and glucan-producing strains otherwise resembling $S$. mitior have often been considered to be $S$. sanguis (see reference 4 for example). Colman and Williams included the " $S$. mitiorlike" glucan-producing strains within $S$. mitior, and others have accepted this grouping $(12,15)$. By using deoxyribonucleic acid (DNA)-DNA base sequence hybridization, we have shown that glucan-producing strains otherwise resembling $S$. mitior are definitely not $S$. sanguis (8). We report here results of DNA base sequence homology experiments designed to show the relationships between the glucan-producing $S$. $m i$ tior-like strains and the glucan-negative $S . m i$ tior strains.

\section{MATERIALS AND METHODS}

Bacterial strains. The streptococcal strains used in this study are listed in Table 1. All fit the description of $S$. mitior as set forth by Colman and Williams (5). They do not ferment mannitol, sorbitol, or inulin and do not hydrolyze arginine or esculin. Fermentation of raffinose varies among the strains. They produce $\mathrm{H}_{2} \mathrm{O}_{2}$. Some strains synthesize glucan from sucrose. When grown on Mitis-salivarius agar (BBL Microbiology Systems, Cockeysville, Md.), which is $5 \%$ sucrose, these bacteria generally form very flat, thin, dull colonies, except the glucan-producers, which produce very hard, domed colonies that depress the agar, and are indistinguishable from $S$. sanguis colonies. When grown for DNA extraction, the cultures were Gramstrained and streaked on Mitis-salivarius agar to confirm purity.

Preparation of DNA. Fresh overnight cultures in $100 \mathrm{ml}$ of Todd-Hewitt broth (BBL) were added to $400 \mathrm{ml}$ of fresh, warm $\left(37^{\circ} \mathrm{C}\right)$ broth containing an additional $1 \%\left(\mathrm{wt} / \mathrm{vol}\right.$ ) glucose and incubated at $37^{\circ} \mathrm{C}$. Bacterial growth was measured turbidimetrically. In 
TABLE 1. Strains used in this study ${ }^{a}$

\begin{tabular}{|c|c|}
\hline Strain & Origin \\
\hline $10557^{b}$ & $\begin{array}{l}\text { Isolated from blood; obtained } \\
\text { from J. Carlsson (see ref. 4); } \\
\text { derived from ATCC strain } \\
10557 \text {, formerly considered } \\
\text { to be S. sanguis (see ref. } 8 \text { ) }\end{array}$ \\
\hline $72 \times 35^{b}$ & $\begin{array}{l}\text { Culture of strain } 10557 \text { ob- } \\
\text { tained from B. Rosan }\end{array}$ \\
\hline $9811^{b}$ & $\begin{array}{l}\text { Obtained from B. Rosan; de- } \\
\text { rived from } S \text {. mitis (mitior) } \\
\text { ATCC strain } 9811\end{array}$ \\
\hline MPD $1,{ }^{b} \mathrm{HPA}^{b}$ & $\begin{array}{l}\text { Isolated by J. Carlsson and ob- } \\
\text { tained from D. Bratthall }\end{array}$ \\
\hline $\begin{array}{l}\text { OP51, HV51, } \\
\text { OS51, NS51 }\end{array}$ & $\begin{array}{l}\text { Isolated by and obtained from } \\
\text { J. Carlsson }\end{array}$ \\
\hline $\begin{array}{l}O T F 1_{\text {flat }} \\
\text { OTF } 1_{\text {beady }}\end{array}$ & $\begin{array}{l}\text { OTF1 isolated by and ob- } \\
\text { tained from J. Carlsson; sub- } \\
\text { strains growing flat colonies } \\
\text { and beady colonies on Mitis- } \\
\text { salivarius agar were estab- } \\
\text { lished }\end{array}$ \\
\hline $\begin{array}{l}\text { FW103, FW69, } \\
\text { BU174 }\end{array}$ & $\begin{array}{l}\text { Isolated by and obtained from } \\
\text { G. Colman (see ref. 5) }\end{array}$ \\
\hline
\end{tabular}

${ }^{a}$ Strain designations are those used by the cited authors.

${ }^{b}$ Produces glucan.

the late logarithmic phase, $10 \mathrm{U}$ of penicillin per ml was added and incubation was continued until growth stopped. The cells were harvested by centrifugation after $7.5 \mathrm{~g}$ of sodium citrate was added, washed twice with $0.015 \mathrm{M}$ tris(hydroxymethyl)aminomethylmethane (Tris) buffer ( $\mathrm{pH} 8$ ), treated with lysozyme $(5 \mathrm{mg}$ in $15 \mathrm{ml}$ of $0.15 \mathrm{M}$ Tris [pH 8]) for $2 \mathrm{~h}$, suspended in $15 \mathrm{ml}$ of saline sodium citrate (SSC; $0.15 \mathrm{M}$ sodium chloride, $0.015 \mathrm{M}$ sodium citrate), and finally lysed by the addition of $0.5 \mathrm{ml}$ of $25 \%$ (wt/vol) sodium lauryl sulfate. After heating for $20 \mathrm{~min}$ at $60^{\circ} \mathrm{C}$, the material was treated with $0.5 \mathrm{ml}$ of $5 \%$ (wt/vol) protease (Sigma Chemical Co., St. Louis, Mo.). For radioactive (index) DNA, $1 \mathrm{mCi}$ of [methyl $-{ }^{3} \mathrm{H}$ ] thymidine (New England Nuclear Corp., Boston, Mass.) was added to the culture medium.

The first stage of DNA purification was deproteinization with phenol and chloroform and precipitation with cold ethanol. The DNA was further purified by two methods. Some was centrifuged to equilibrium in $\mathrm{CsCl}$ as follows. The precipitated DNA was dissolved in $0.03 \mathrm{M}$ Tris- $0.005 \mathrm{M}$ ethylenediaminetetraacetic acid-0.05 $\mathrm{M} \mathrm{NaCl}$. A 4-ml volume of the solution was added to $25 \mathrm{ml}$ of a CsCl solution (about $127 \mathrm{~g}$ of $\mathrm{CsCl}$ dissolved in $100 \mathrm{ml}$ of water), and the density was adjusted to exactly $1.70 \mathrm{~g} / \mathrm{cm}^{3}$ by the addition of more $\mathrm{CsCl}$. This mixture was centrifuged at $40,000 \mathrm{rpm}$ for $36 \mathrm{~h}$ in a Beckman $60 \mathrm{Ti}$ rotor at $15^{\circ} \mathrm{C}$. After centrifugation, the DNA was collected by puncturing the bottom of the tube and collecting the viscous fraction. The DNA solution was then dialyzed against $0.42 \mathrm{M}$ $\mathrm{NaCl}$ for 2 days at $5^{\circ} \mathrm{C}$ with five changes of the salt solution.

Other DNA was purified by dissolving the deproteinized nucleic acid in SSC/100 and treating it with ribonuclease A (Sigma) at a concentration of $50 \mathrm{U} / \mathrm{ml}$ of DNA solution for $30 \mathrm{~min}$ at $60^{\circ} \mathrm{C}$ and $30 \mathrm{~min}$ at $37^{\circ} \mathrm{C}$, followed by incubation for $2 \mathrm{~h}$ at $37^{\circ} \mathrm{C}$ with protease (at $0.05 \%$ [wt/vol]) and sodium lauryl sulfate (at $0.5 \%$ [wt/vol]). Finally, the mixture was deproteinized again with phenol and chloroform and precipitated in cold ethanol. This DNA was redissolved in dilute saline and dialyzed against $0.42 \mathrm{M} \mathrm{NaCl}$ as described above. This DNA is referred to below as "conventional DNA."

The purified DNA was quantitated by the absorption of ultraviolet light at $260 \mathrm{~nm}$, assuming that 10 $\mu \mathrm{g}$ of DNA per ml results in a reading of 0.250 . The ratios of absorbance at 230:260:270:280 nm were consistently about $0.44: 1: 0.82: 0.54$. DNA was prepared from most strains by both of the above methods.

When sheared DNA was required, it was disrupted by sonic treatment with a model 185 sonifier (Heat Systems-Ultrasonics, Inc., Plainview, N.Y.), using a 3$\mathrm{mm}$ tip at the number-two power setting $(38 \mathrm{~W})$ for 1 $\min$ in $15-\mathrm{s}$ bursts. The DNA was in a $13-\mathrm{mm}$ tube immersed in ice water. This treatment preceded dialysis so that small bits of DNA (below 12,000 molecular weight, or about 25 base pairs) would be eliminated.

Hybridization by the $\mathrm{S1}$ nuclease method. The method described by Barth and Grinter (2) was used. Single-strand-specific $S 1$ endonuclease was used to eliminate unreassociated and incompletely reassociated DNA. A 25- $\mu \mathrm{g}$ portion of sheared DNA was mixed with $0.05 \mu \mathrm{g}$ of sheared, labeled "index" DNA in a total volume of $1.25 \mathrm{ml}$ of $0.42 \mathrm{M} \mathrm{NaCl}$ in siliconized test tubes. These mixtures were denatured in a water-ethylene glycol bath at 103 to $105^{\circ} \mathrm{C}$ for $20 \mathrm{~min}$ (this species of DNA denatures at 90 to $91^{\circ} \mathrm{C}$ in 0.42 $\mathrm{M} \mathrm{NaCl}$ ). The mixtures were then incubated at $65^{\circ} \mathrm{C}$ for 6 to $7 \mathrm{~h}$. This short incubation time (about $2 \times$ $\mathrm{C}_{0} \mathrm{t}_{1 / 2}$ ) was used since it resulted in adequate heteroduplex formation, and the self-reassociation of labeled DNA was minimized. In some experiments, the amount of label used was increased 10 -fold, which resulted in some unobjectionable self-reassociation of the index DNA under these conditions.

In each experiment, DNA from $E$. coli and/or calf thymus (Sigma; sheared and dialyzed, as the other DNA) was included. All hybridizations were performed in duplicate. After $6 \mathrm{~h}$, the hybridization mixtures were treated with $\mathrm{S} 1$ nuclease as follows. To each mixture was added $1.8 \mathrm{ml}$ of "reaction mixture" (50 mM sodium acetate-1.67 $\mathrm{mM} \mathrm{ZnSO}_{4}[\mathrm{pH} \mathrm{4.8]),} 25$ $\mu \mathrm{g}$ of sheared, denatured calf thymus DNA, and $20 \mathrm{U}$ of $\mathrm{S} 1$ nuclease. The mixtures were then returned to $65^{\circ} \mathrm{C}$ for $20 \mathrm{~min}$. The mixtures were then placed in ice water, and $3.2 \mathrm{ml}$ of ice-cold trichloroacetic acid (10\% [wt/vol]) was added to stop the reaction and precipitate the DNA.

Three pairs of control mixtures were included. All were mixtures of $25 \mu \mathrm{g}$ of calf thymus DNA and 0.05 $\mu \mathrm{g}$ of index DNA. One pair was not denatured and did not receive $\mathrm{S} 1$ nuclease. When precipitated, this DNA represented the maximum labeled DNA recoverable. Another pair was not denatured but received S1 nuclease. This tested the effect of the enzyme on doublestranded DNA. The remaining pair of controls was denatured and treated with S1 nuclease immediately after cooling to $65^{\circ} \mathrm{C}$, to test the efficiency of the enzyme against single-stranded DNA. Radioactive 
counts from this control were considered "background."

The precipitated DNA was collected on glass-fiber filters (Whatman GF/C). The filters were prerinsed with $4 \mathrm{ml}$ of $5 \%$ trichloroacetic acid (wt/vol) containing $0.2 \mathrm{mM}$ thymine. The DNA was filtered, and then the filters were rinsed four times with $4 \mathrm{ml}$ of $5 \%$ acid with thymine, the first $4 \mathrm{ml}$ being used to rinse the reaction tube that had contained the DNA. After a final rinse with $2.5 \mathrm{ml}$ of acetone, the filters were dried, and entrapped labeled DNA (hybrids) was counted by liquid scintillation using a commercial scintillant (Aquasol, New England Nuclear).

The degree of relative hybridization, or "homology," was calculated by subtracting the "background" from all reassociation counts and comparing heterologous reassociation (hybrid) values to the homologous control (labeled index DNA reassociated with unlabeled DNA of the same strain).

Hybridization on filters. For comparison, some tests of DNA homology were undertaken by the filter method of Denhardt (10). Solutions of $50 \mu \mathrm{g}$ of denatured, unsheared DNA in $6 \times$ SSC were applied to 25mm filters (HAWP, Millipore Corp., Bedford, Mass.), dried, and incubated as described by Denhardt (10), with 1 or $0.5 \mu \mathrm{g}$ of sheared, denatured index DNA. After incubation overnight at $67^{\circ} \mathrm{C}$, the filters were rinsed in $3 \times$ SSC, dried, and counted as described above.

With DNA prepared by two methods and hybridizations done by two methods, four types of experiments were possible. Most of the DNA was used in the S1 nuclease experiments. The DNA from only a few strains was used in the filter experiments.

Determination of DNA base content. The base content (moles percent guanine plus cytosine $[\mathrm{G}+\mathrm{C}]$ ) of each strain's DNA was determined three to five times by thermal denaturation, using the formula: $\mathrm{mol} \% \mathrm{G}+\mathrm{C}=\left(T_{m}-69.3\right) / 0.41(14)$.

\section{RESULTS}

Effectiveness of the S1 method. Using 20 $\mathrm{U}$ of $\mathrm{S} 1$ nuclease per reaction mixture, it was possible to eliminate $90 \%$ of the single-stranded DNA in $20 \mathrm{~min}$. The amount of trichloroacetic acid-precipitable DNA was very similar between duplicate hybridization mixtures. Using a 500:1 ratio of unlabeled DNA to index DNA, the amount of labeled, precipitated DNA from the control mixtures containing $E$. coli or calf thymus DNA was seldom much higher than that of background. When the ratio was reduced to 50:1, these mixtures yielded amounts of precipitable DNA of 5 to $7 \%$ of the homologous control. This probably represents the formation of homoduplexes of labeled DNA at this proportionally higher concentration, which resulted in a slight inflation of the relative hybridization values of the $S$. mitior strains.

Hybridizations. The degree of DNA-DNA hybridizations between DNA from different strains was never high when the S1 nuclease method was used (Table 2). The results indicate the existence of two groups of strains, arbitrarily called 1 and 2. DNA from strains in group 1 hybridized between 60 and $80 \%$ with the index strains 10557 and OP51 (DNA of strain $72 \times 35$ hybridized almost completely with 10557 DNA, but they are actually the same strain [see Table 1], and this was expected). DNAs from the strains of group 2 hybridized about 30 to $35 \%$ with the group 1 index DNAs.

When DNAs of strains in group 2 were used as index DNAs, the reciprocal results were seen. Within this group, hybridizations were 60 to $75 \%$ with index strains FW103 and NS51, although strain FW69 DNA always hybridized less. The group 1 DNAs hybridized only 30 to $40 \%$ with the group 2 index strain DNAs in two experiments, and 40 to $50 \%$ in one experiment. The DNA purification method ( $\mathrm{CsCl}$ versus conventional method) did not seem to have any effect on the results.

When the filter hybridization method was used, the degree of hybridization was always significantly higher, but paralleled the results of the S1 method hybridizations.

All of the glucan-producing strains joined group 1.

$\mathrm{G}+\mathrm{C}$ contents. The DNA $\mathrm{G}+\mathrm{C}$ contents of the strains are listed in Table 3. There is a slight, but significant $(P<0.01)$, difference between the mean base contents of the two groups: 42.14 mol \% for group 1 and $40.44 \mathrm{~mol} \%$ for group 2 .

\section{DISCUSSION}

We consider bacterial strains whose DNAs are $80 \%$ homologous (in the membrane filter technique) to form "genospecies," i.e., organisms that have similar genetic molecules. (We would like to have genospecies and species be synonymous.) In the case of these $S$. mitior strains, it is clear that DNA base sequences of members of group 1 are significantly different from those of members of group 2. Indeed, the small but significant difference in the mean base contents of the two groups predicts some sequence dissimilarity. Strains within the groups were usually over $80 \%$ homologous in the few filter experiments that were done and in one previous experiment with glucan-producing strains (8), but the lower hybridization with the $\mathrm{S} 1$ nuclease method indicates a degree of heterogeneity within the groups also.

We believe that the strains within each group may have areas in their genomes which are not species-specific. The fact that strain $72 \times 35$ hybridized to nearly $100 \%$ with strain 10557 DNA in $\mathrm{S} 1$ experiments indicates that the lack of higher hybridization values among the other strains within each group was not purely technical, and that there are indeed areas in the 
TABLE 2. Degree of DNA homology between strains ${ }^{a}$

\begin{tabular}{|c|c|c|c|c|c|c|c|c|c|c|}
\hline \multirow{3}{*}{ Unlabeled DNA } & \multicolumn{10}{|c|}{ Index (labeled) DNA } \\
\hline & \multicolumn{3}{|c|}{10557} & \multicolumn{3}{|c|}{ OP51 } & \multicolumn{2}{|c|}{ FW103 } & \multicolumn{2}{|c|}{ NS51 } \\
\hline & $\mathrm{CsS}^{b}$ & $\cos 1$ & $\mathrm{CoF}$ & $\mathrm{CsS} 1$ & $\operatorname{CoS} 1$ & CsF & CsS1 & CsF & $\mathrm{CsS} 1$ & $\operatorname{CoS} 1$ \\
\hline \multicolumn{11}{|l|}{ Group 1} \\
\hline $10557^{c}$ & 100 & 100 & 100 & 70.1 & 76.9 & - & 39.9 & - & 32.8 & 48.0 \\
\hline $72 \times 35^{c}$ & 96.5 & 97.3 & 90.6 & 69.4 & 70.7 & 87.5 & 40.3 & 61.8 & 30.4 & 44.1 \\
\hline $9811^{c}$ & 63.9 & $-^{d}$ & - & 64.4 & 73.5 & 75.9 & 36.1 & 64.6 & 31.1 & 43.8 \\
\hline $\mathrm{MPD}^{c}{ }^{c}$ & 73.1 & 60.2 & 89.4 & 65.6 & 63.7 & 88.6 & 37.0 & 60.9 & 30.2 & 48.7 \\
\hline $\mathrm{HPAl}^{c}$ & 63.2 & - & 91.3 & 65.2 & 79.6 & - & 38.6 & - & 34.4 & 43.2 \\
\hline $\mathrm{BU} 174^{c}$ & 65.0 & - & - & 60.0 & 75.3 & - & - & - & - & 45.8 \\
\hline OP51 & 65.4 & 64.4 & - & 100 & 100 & 100 & 40.7 & 60.0 & 34.1 & 48.4 \\
\hline$O T F 1_{\text {flat }}$ & - & - & - & - & 74.0 & - & - & - & - & 41.3 \\
\hline $\mathrm{OTF} 1_{\text {beady }}$ & 64.6 & - & 一 & 68.0 & 80.6 & 83.5 & 37.5 & 一 & 31.7 & 41.3 \\
\hline \multicolumn{11}{|l|}{ Group 2} \\
\hline HV51 & 32.3 & - & - & 29.8 & 56.3 & $\mathbf{5 7 . 9}$ & 64.8 & 75.0 & 67.9 & 73.6 \\
\hline OS51 & 32.4 & 21.9 & - & 35.4 & 50.4 & - & 60.0 & - & 58.7 & 67.9 \\
\hline NS51 & 35.1 & - & 一 & 37.9 & 27.5 & - & 67.4 & - & 100 & 100 \\
\hline FW103 & 30.8 & - & - & 36.8 & 37.0 & $\mathbf{5 7 . 4}$ & 100 & 100 & 68.5 & 72.1 \\
\hline FW69 & 33.9 & - & - & 33.2 & 16.2 & - & 49.2 & - & 53.0 & 62.8 \\
\hline Escherichia coli & 5.0 & 6.9 & 4.5 & 0 & 5.5 & 6.7 & 2.0 & 6.4 & 0 & 6.3 \\
\hline Calf thymus & 1.8 & - & - & 0 & - & - & 3.6 & - & 0 & - \\
\hline
\end{tabular}

${ }^{a}$ Expressed as percent hybrid duplex formation compared to homologous duplex formation.

${ }^{b}$ Abbreviations denote the type of experiment; CsCl-purified DNA, using the $\mathrm{S} 1$ nuclease method (CsC1); $\mathrm{CsCl}$ DNA, using the filter method (CsF); conventionally purified DNA, using the S1 method (CoS1); conventional DNA, using the filter method (CoF).

' Strain that produces glucan.

${ }^{d}$ Hybridization not done.

TABLE 3. DNA base contents of the strains

\begin{tabular}{lllc}
\hline \multicolumn{1}{c}{ Strain } & Mol\% G+C & \pm SD $^{a}$ & $\begin{array}{c}\text { Raffinose } \\
\text { fermenta- } \\
\text { tion }^{b}\end{array}$ \\
\hline Group 1 & & & \\
10557 & 42.2 & 0.71 & + \\
$72 \times 35$ & 42.6 & 0.52 & + \\
9811 & 42.2 & 0.41 & - \\
MPD1 & 42.5 & 0 & + \\
HPA1 & 42.1 & 0.42 & + \\
BU174 & 42.4 & 0.36 & + \\
OP51 & 42.2 & 1.01 & + \\
OTF1 & 41.8 & 0.36 & - \\
OTF1 1 beady & 41.3 & 0.89 & - \\
& & & \\
Group 2 & & & + \\
HV51 & 40.8 & 0.91 & + \\
OS51 & 40.2 & 1.04 & - \\
NS51 & 41.0 & 1.14 & + \\
FW103 & 40.3 & 0.26 & - \\
FW69 & 39.9 & 0.35 & - \\
\hline
\end{tabular}

${ }^{a}$ SD, Standard deviation.

${ }^{b}+$, Acid produced; - , no acid produced.

genomes of these strains which are not homologous. Thus, these $S$. mitior genomes may have areas where their base sequences are similar but not identical, so that these sequences can form weak, infidelical heteroduplexes which contain many mismatched base pairs. These duplexes can appear as hybrids on membrane filters, but cannot endure treatment with $\mathrm{S} 1$ nuclease.

Additional experiments support the idea that these strains have base sequence heterogeneities detectable by $\mathrm{S} 1$ nuclease treatment and that the lack of complete homology was not a technical artifact. DNA was extracted by the conventional method from four strains of $S$. sobrinus (mutans) (7). These strains are known to have great DNA base sequence homology (6). Using the membrane filter method, these DNAs showed 96 to $98 \%$ homology. When these same DNAs were tested by the S1 method, their homology did not decrease.

Thus, these $S$. mitior strains show a degree of genetic heterogeneity consistent with the oftennoted phenotypic heterogeneity, even though these particular strains form a reasonably homogeneous group based on their reactions to arginine, esculin, and inulin. It seems likely that considerable base sequence divergence has occurred in the DNA of this "species." Heterogeneities found among fructose diphosphate aldolases of $S$. mitis (mitior) strains (13) also indicate evolutionary divergence.

Facklam has suggested a taxonomic scheme for viridans streptococci which includes a "Type I" S. sanguis, a "Type II" S. sanguis, and $S$. mitis (11). $S$. sanguis II and $S$. mitis are similar; 
they seldom split arginine and never split esculin or ferment inulin. They are differentiated by raffinose; $S$. sanguis II ferments this sugar whereas $S$. mitis does not. We consider Facklam's $S$. sanguis II and $S$. mitis strains to be $S$. mitior strains, especially since we find raffinose fermentation of no value in identifying either $S$. mitior (Table 3) or S. sanguis.

Our results show that $S$. mitior strains which produce glucan are genetically indistinguishable from others that do not, and therefore this trait has little taxonomic significance. However, the production of these polymers may have ecological and pathological importance. The glucan producers are more often found on tooth surfaces (4), and Parker and Ball suggest that dextran production enhances the probability that such a streptococcus will cause endocarditis (15).

\section{ACKNOWLEDGMENTS}

This work was supported by the Veterans Administration, General Medical Research Funds, and by a grant from the University of Connecticut Research Foundation.

We thank Clark Tibbetts for his advice and the use of his facilities, and Pauline Lizotte for the determination of DNA base contents.

\section{REPRINT REQUESTS}

Address reprint requests to: Dr. Alan L. Coykendall, University of Connecticut Health Center, Oral Diagnosis, Farmington, CT 06032.

\section{LITERATURE CITED}

1. Andrewes, F. W., and T. J. Horder. 1906 A study of the streptococci pathogenic for man. Lancet ii:708-713.

2. Barth, P. T., and N. J. Grinter. 1975. Assay of deoxyribonucleic acid homology using a single-strand-specific nuclease at 75 C. J. Bacteriol. 121:434-441.

3. Buchanan, R. E., J. G. Holt, and E. F. Lessel, Jr. (ed). 1966. Index Bergeyana, p. 1084-1085. The Williams and Wilkins Co., Baltimore.

4. Carlsson, J. 1968. A numerical taxonomic study of hu- man oral streptococci. Odontol. Revy 19:137-160.

5. Colman, G., and R. E. O. Williams. 1972. Taxonomy of some human viridans streptococci, p. 282-299. In L. W. Wannamaker and J. M. Matsen (ed.), Streptococci and streptococcal diseases. Academic Press Inc., New York.

6. Coykendall, A. L. 1974. Four types of Streptococcus mutans based on their genetic, antigenic and biochemical characteristics. J. Gen. Microbiol. 83:327-338.

7. Coykendall, A. L. 1977. Proposal to elevate the subspecies of Streptococcus mutans to species status, based on their molecular composition. Int. J. Syst. Bacteriol. 27:26-30.

8. Coykendall, A. L., and P. A. Specht. 1975. DNA base sequence homologies among strains of Streptococcus sanguis. J. Gen. Microbiol. 91:92-98.

9. Deibel, R. H., and H. W. Seeley, Jr. 1974. Genus I. Streptococcus Rosenbach 1884, 22, p. 490-509. In R. E. Buchanan and N. E. Gibbons (ed.), Bergey's manual of determinative bacteriology, 8th ed. The Williams and Wilkins Co., Baltimore.

10. Denhardt, D. T. 1966. A membrane-filter technique for the detection of complementary DNA. Biochem. Biophys. Res. Commun. 23:641-646.

11. Facklam, R. R. 1977. Physiological differentiation of viridans streptococci. J. Clin. Microbiol. 5:184-201.

12. Hardie, J. M., and G. H. Bowden. 1974. The normal microbial flora of the mouth, p. 47-83. In F. A. Skinner and J. G. Carr (ed.), The normal microbial flora of man. Society for Applied Microbiology Symposium Series no. 3. Academic Press Inc., London.

13. London, J., N. M. Chace, and K. Kline. 1975. Aldolase of lactic acid bacteria: immunological relationships among aldolases of streptococci and gram-positive nonsporeforming anaerobes. Int. J. Syst. Bacteriol. 25:114-123.

14. Marmur, J., and P. Doty. 1962. Determination of the base composition of deoxyribonucleic acid from its thermal denaturation temperature. J. Mol. Biol. 5:109-118.

15. Parker, M. T., and L. C. Ball. 1976. Streptococci and aerococci associated with systemic infection in man. J. Med. Microbiol. 9:275-302.

16. Schottmüller, H. 1903. Die Artunterscheidung der für den Menschen pathogenen Streptokokken durch Blutagar. Muench. Med. Wochenschr. 50:849-853.

17. Sherman, J. M., C. F. Niven, Jr., and K. L. Smiley. 1943. Streptococcus salivarius and other non-hemolytic streptococci of the human throat. J. Bacteriol. 45:249-263. 